Elżbieta Bajkiewicz-Grabowska, Zdzisław Mikulski

\title{
WATER AND SOLID MATTER CIRCULATION IN THE ALLUVIAL RIVER VALLEY
}

\author{
STRUCTURE OF THE ALLUVIAL VALLEY
}

The river valley is a geomorphological unit formed as a result of erosive and accumulative action of the flowing water. Its development depends on the relief, geological structure of the bed-rock and climate. The valley is composed of the bottom and slopes, the structure of which determines the type of the valley. The valley bottom is primarily formed by the fluvial processes, while the slopes are shaped by the slope processes.

In Poland the bottoms of large river valleys are occupied by the terrace levels, the lowest of which (floodplain and overflood plain) were shaped over the past 10-13 thousand years in the late Glacial and Holocene (Starkel 1991). They are characterized by the multi-layer composition of the alluvia. In the simplest case, there are two principal cycles of sedimentation: the fluvio-glacial cycle occurring in the floor and the overlying fluvial deposits (Falkowski 1971; Górski 1981; Macioszczyk 1988). Fluvio-glacial formations include coarse-grained sand and gravel of considerable thickness, but organic substance is almost missing. The overlying alluvial deposits are usually less thick, more fine-grained, and they are often represented at the top by silt or mud formations and even by peat and loamy formations. Thus, the main components of the fluvial alluvia are sands, usually quartz sands, as well as loams, gravels, silts, alluvial soils from flood and peats. Among fluvial deposits the following facies can be found:

- the coarse-grained ill-sorted facies of the river channel with a variety of well-sorted sandbanks,

- the facies of fillings of oxbows (fluvial, lacustrine and marsh and peat deposits);

- the facies of flood plains, consisting of sand formations of the river channel embankments and silty-marsh depressions. 


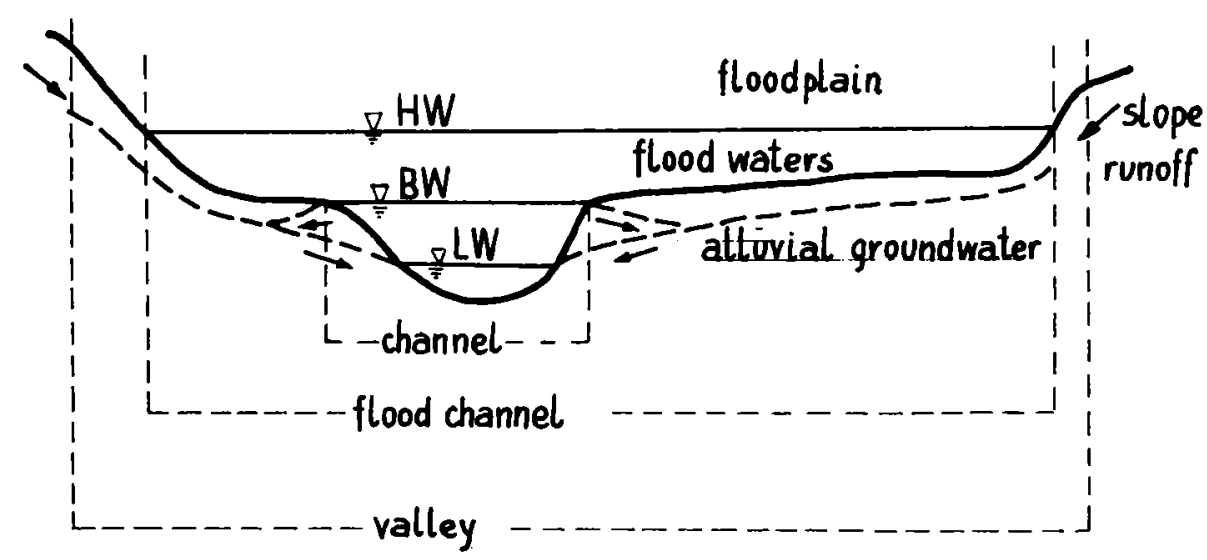

Fig. 1. Cross-section of the river valley: $\mathrm{HW}-$ high stage, $\mathrm{BW}-$ bankfull stage, $\mathrm{LW}-$ low stage

\section{WATER CIRCULATION IN THE ALLUVIAL VALLEY}

The alluvial valleys are usually supplied with water from subsurface catchments (Fig. 1). Therefore it is characteristic that they are a full hydraulic link between waters in the alluvial formations and the main water-bearing layer of the subsurface catchment (Poźniak 1988).

The geo-system of the river valley bottom may be supplied with water directly or indirectly through:

- infiltration of atmospheric precipitation;

- infiltration of surface water from the river channel, drainage ditches, oxbows etc.;

- lateral tributaries (e.g. from glacial uplands and watersheds of the smaller rivers);

- local tributaries.

Generally speaking, in the alluvial draining river the largest part of the infiltration supply consists of subsurface layers of terrace formations. At the higher Pleistocene terraces, in their deepest strata, the share of the lateral recharge from uplands increases. This is groundwater connected with the circulation of the near range, coming also from infiltration of atmospheric precipitation which has fallen over uplands. The deepest parts of the alluvia, particularly in the central part of the valley, are mostly fed by side inflow and in some cases by a local tributary (Fig. 2). In these parts of the valleys drainage of waters of the long distance circulation may occur. For example, according to Macioszczyk (1988) the Vistula river valley is draining inside the Mazovian Lowland waters from Quaternary, Tertiary or even Cretaceous formations. 

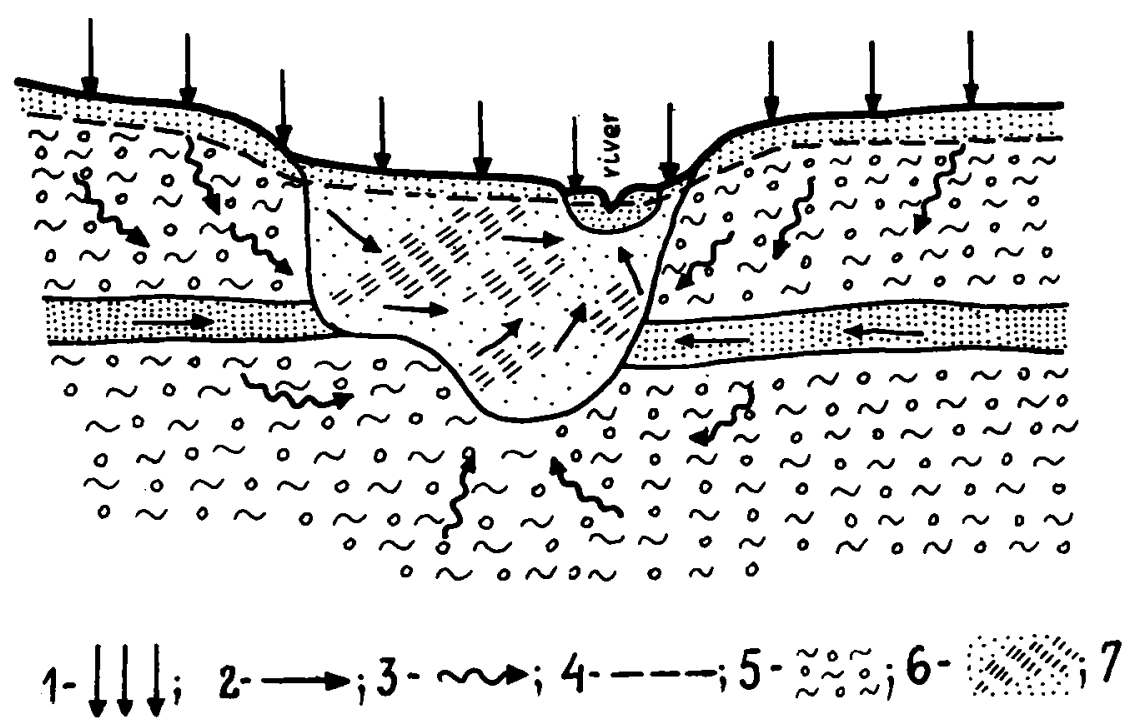

Fig. 2. Scheme of recharge of alluvial valley in the region of Lowlands in Poland (after Macioszczyk 1988); 1 - infiltration of atmospheric precipitation, 2 - directions of water flow, 3 - directions of infiltration of groundwater, $4-$ groundwater table, $5-$ clays, 6 - loamy sands, 7 - sands

\section{THE HYDROLOGICAL SYSTEM OF THE ALLUVIAL VALLEY}

Water circulation in the river valley may be represented schematically (Fig. 3), considering the alluvial valley as a storage reservoir $\left(R_{d}\right)$ It has three types of recharge:

- atmospheric precipitation over the valley surface $(P)$;

- "side" recharge, perpendicular to the valley which consists of: (1) surface and subsurface flow $\left(\mathrm{H}_{\mathrm{s}}\right)$ from the valley slope, and (2) infiltration from the river channel of the high stages during the flood $\left(\mathrm{H}_{\mathrm{inf}}\right)$;

- "longitudinal" recharge, parallel to the valley which follows its slope, comprising: (1) inflow of alluvial waters $\left(\mathrm{H}_{\mathrm{al}}\right)$ from the higher section of the valley, and (2) periodic inflow of the flood water $\left(\mathrm{H}_{f}\right)$ from the higher section of the valley.

The outgoing part is composed of:

- evapotranspiration from the valley area $(E)$,

- discharge of groundwater to the river channel $\left(\mathrm{H}_{\mathrm{gr}}\right)$

- "longitudinal" runoff from the flood plain being a sum of: (1) outflow of alluvial water to the lower section of the valley $\left(\mathrm{H}_{\mathrm{al}}^{\prime}\right)$, and (2) outflow of flood water to the lower section of the valley $\left(\mathrm{H}_{\mathrm{f}}^{\prime}\right)$.

The difference between the receipts and expenditure is regulated by retention of the alluvial valley $\left(\Delta R_{v}\right)$.

Thus, the water balance of the alluvial valley may be represented as 
$\left(\mathrm{P}+\mathrm{H}_{\mathrm{c}}+\mathrm{H}_{\mathrm{in}}+\mathrm{H}_{\mathrm{al}}+\mathrm{H}_{\mathrm{s}}-\left(\mathrm{E}+\mathrm{H}_{\mathrm{gr}}+\mathrm{H}_{\mathrm{al}}^{\prime}+\mathrm{H}_{\mathrm{f}}^{\prime}\right)=\Delta \mathrm{R}_{\mathrm{v}}\right.$ $(\mathrm{P}-\mathrm{E})+\mathrm{H}_{\mathrm{c}}+\left(\mathrm{H}_{\mathrm{inf}} \mathrm{H}_{\mathrm{gr}}\right)+\left(\mathrm{H}_{\mathrm{al}}-\mathrm{H}_{\mathrm{al}}^{\mathrm{gr}}\right)+\left(\mathrm{H}_{\mathrm{r}} \mathrm{H}_{\mathrm{f}}^{\prime}\right)=\Delta \mathrm{R}_{\mathrm{v}}$

Water circulation links all the elements of the natural environment of the alluvial valley, i.e. atmosphere, hydrosphere, lithosphere, pedosphere and biosphere.

\section{HYDROGEOCHEMICAL ENVIRONMENT OF THE ALLUVIAL VALLEYS}

Groundwater is the main element of the natural environment of the alluvial valleys. Conditions of its occurrence, development, composition and physico-chemical properties certainly depend on this environment to a large extent. On the other hand, groundwater directly determines the specificity of the natural environment of the river valleys (e.g. it controls the development and intensification of the soil processes, participates in creation of

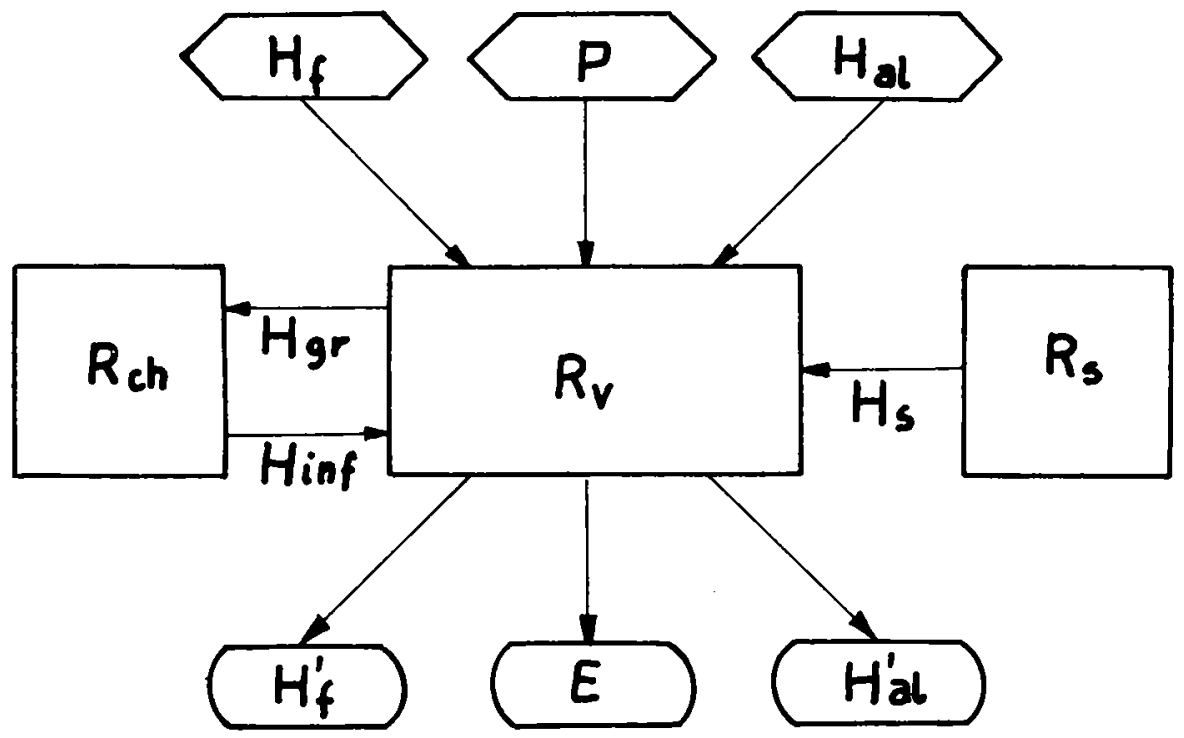

Fig. 3. Hydrological system of alluvial valley; $\mathrm{P}-$ atmospheric precipitation, $\mathrm{H}_{\mathrm{f}}-$ flood inflow, $\mathrm{H}_{\mathrm{al}}$ - alluvial inflow, $\mathrm{H}_{\mathrm{gr}}-$ groundwater discharge, $\mathrm{H}_{\mathrm{inf}}$ - bank filtration, $\mathrm{H}_{-}-$valley slope discharge, $\mathrm{H}_{\mathrm{f}}-$ flood outflow, $\mathrm{H}_{\mathrm{al}}-$ alluvial outflow, $\mathrm{R}_{\mathrm{ch}}-$ channel storage, $\mathrm{R}_{\mathrm{v}}-$ flood plain storage, $R_{B}-$ valley slope storage, $E$ - aerial evaporation

micro-climate of the valleys and determines the types of biocenoses).

Hydrogeochemical environment of the alluvial valleys depends on a number of factors; the chemical property of groundwater is mainly shaped by the following conditions: geology, soils, hydrogeology, biocenoses, climate, hydrography as well as morphology. Their chemical composition is also affected by the economic activity. 
Groundwater in the alluvial valleys most frequently occurs in the fluvial forms represented by well-washed and evenly granulated medium- and thick-grained sands and gravels; within the higher terraces the sands are not so well-sorted. In the petrographic composition of these formations crystalline and limestone rocks are prevalent (Skompski 1969). The environment of groundwater in the alluvial valleys is also characterized by the occurrence of alluvial soil from floods. Specific of these valleys are also sand dunes occurring on the terraces and fluvioglacial forms separated by peat depressions (Pich 1980).

From the hydrochemical viewpoint an important feature of geological structure of the river valleys is that sand formations within terraces usually form one water-bearing complex. If there occur impermeable silt layers, they are only of local importance.

In the alluvial river valleys, in terms of the type of geological structure, hydrogeological relations and morphological features, the most frequently occurring are sandy soils, brown soils, muds, swamp-marsh and marshy soils. The soil cover in the alluvial valleys through close contacts with groundwater influences its chemical composition. This is mainly due to the infiltration water, which regulates the groundwater table; of secondary importance is the periodic rise of groundwater table caused by the river waters infiltrating from the channel.

In the longitudinal profile the following three layers of soils can be distinguished:

- upper layer, abundant in soluble and decomposed mineral components as well as humus substance; it undergoes intensive weathering and is enriched with mineral and organic salts;

- middle layer, which differs from the upper one in that it contains a larger number of coarser mineral grains because the weathering is already less intensive; it is enriched with products from the upper layer, organic material is oxidized here, and iron and manganese are precipitated;

- lower layer, being the basement of the parent rock; the process of mineral weathering is very weak and there is an equilibrium of salt solubility.

In these layers a continuing physico-chemical transformation takes place due to precipitation water infiltrating through the upper and middle layer, as well as due to water rising in a capilary fringe from the lower layer. Besides, this water movement creates in the soil at definite depths the level of leaching which is deprived of humus matter and iron hydroxide, as well as the level of sedimentation with precipitated iron and aluminium compounds.

Inflitration of precipitation water causes that in peaty and marshy areas groundwater is enriched with a considerable amount of organic substance and iron in the shape of complex humus compounds, whereas the concentration of the main ions is small. The situation is similar in the case of water infiltrating through sandy formations, although iron does not occur 
in them (Laherno 1970; Perelman 1971). In the course of infiltration of precipitation water through soil, part of oxygen dissolved in them is used to oxidize organic substance. This phenomenon leads to the increase of $\mathrm{CO}_{2}$ in water, which in turn precipitates the dissolution process.

The soils of the alluvial valleys not only affect the chemical composition of the precipitation water infiltrating through them but may also change the previously formed chemical composition of groundwater. This may occur in the case of their sufficiently long-lasting contact with groundwater via exchange with the ions absorbed by the soil.

A direct effect on the formation of chemical composition of the alluvial waters is mainly attributed to loamy minerals and organic substance. Loamy minerals take an active part in the sorption processes and limit infiltration of precipitation waters. The organic substance also shows sorption capacity, as well as is capable of forming complex compounds. Its occurrence in deposits leads to decreasing redox potential and the increasing acidifying of waters. Decomposition of organic substance enriches groundwater with many hydrochemical elements (e.g. sulphur, nitrogen, iron compounds and numerous micro-elements).

Frequent changes of the level of table of alluvial waters result in variable contact of groundwater with the layer of soil and subsoil which in turn causes a great diversity of overlapping processes, such as, for example, leaching, or ion exchange. The investigations conducted so far show that changes in hydrogeochemical environment are most strongly marked in the upper laver of the water-bearing layer within the range of oscillations of the water table. These changes mostly concern the factors of aggressiveness of the environment $\left(\mathrm{CO}_{2}\right.$ contents, acidity, $\left.\mathrm{pH}\right)$ and the resultant contents of iron and manganese. These changes are caused by oxidation of iron sulphides (their occurrence in the soil environment is associated in the first place with the presence of organic compounds) in the zone of the diminished water table. The sulphurous acid released in this process causes the decreasing $\mathrm{pH}$ of the environment and increasing general mineralization.

The soil environment is characterized by a selective capacity of cation adsorption, which permits replacement of some cations by others, According to the adsorption ability by soils, cations form the following sequence: $\mathrm{Na}^{+}$, $\mathrm{K}^{+}, \mathrm{NH}_{4}^{+}, \mathrm{Mg}^{+2}, \mathrm{Ca}^{+2}, \mathrm{H}^{+}$(Alekin 1956). This indicates that only with the sufficiently high concentration of sodium a part of calcium ions will be replaced by the sodium ions from the adsorption set. These complex processes of leaching and ion exchange always tend to achieve the state of chemical equilibrium in accordance with the reaction

$2 \mathrm{Na}^{+}+\mathrm{Ca}$ (absorbed) $\Leftarrow===\Rightarrow \mathrm{Ca}^{2}+2 \mathrm{Na}$ (adsorbed).

If the precipitation waters supply increasingly new amounts of calcium and manganese to the neutral or alkaline soils, the reaction will be moving to the left, which favours the leaching of $\mathrm{Na}^{+}$.

In the physico-chemical processes discussed above the role of potassium and - to a lesser extent - ammonia is more complex than the role of 
sodium, calcium and manganese (Pich 1980 ). The ions of $\mathrm{K}^{+}$react like the ions of $\mathrm{Na}^{+}$, but at the same time they may be permanently adsorbed and thereby excluded from the circulation soil - groundwater and vice versa (Golterman 1967). Unlike cations, not much is known about the behaviour of the main anions in ion exchange processes (Pich 1980).

Chemical composition of groundwater largely depends on recharge and drainage conditions, speed of water movement, extent of oscillations and depth of occurrence of waters, type of water-bearing layers, as well as degree of contact with surface and subsurface waters from deeper levels. The river valleys have specific hydrogeological conditions which find reflection in that:

- geological structure of valleys and lithology of their formations provide very advantageous conditions for water circulation;

- they are a drainage zone of subsurface waters so that circulation of groundwater is intensive (it is the area of a full drainage of susurface waters);

- they reflect the impact of hydrological regime of rivers on the system of alluvial waters.

\section{CHEMICAL COMPOSITION OF THE VALLEY WATERS}

Groundwater of the alluvial valleys has a fairly characteristic chemical composition and physical properties (Górski 1981). It is characteristic that considering the conditions of the zone of active exchange of waters, they have a relatively high oxidation and hardness (Table 1). Likewise, the quality of the alluvial waters is not too advantageous due to increased content of iron and manganese compounds. In terms of iron content, these waters resemble waters not from the environment of the river formations but the waters from the environment of fluvio-glacial formations under the boulder clays (Plochniewski, Pich 1966), while the manganese content in these waters corresponds to the environment of the river waters (Table 2).

Within Quaternary valley formations of Central Poland (Mazovian Lowland) there occur regular waters (fresh) of fairly differentiated general mineralization (sum of dissolved constant components); in the Plock Valley it ranges from 98 to $1749 \mathrm{mg} / 1$ (Pich 1980). Valley waters belong to the type of bicarbonate sulphate and chloride waters. The proportion of bicarbonates is dominant and waters in which sulphates prevail are rare, while waters where chlorides prevail are sporadic (Pich 1980; Bajkiewicz-Grabowska 1988). In the group of bicarbonate waters these are most frequently bicarbonate and sulphate waters as well as bicarbonate-sulphate-chloride waters; in the group where sulphates are prevalent these are usually sulphate-bicarbonate and sulphate-chloride-bicarbonate waters. Relations of the main cations are most often formed by waters of the type $\mathrm{Ca}^{+2}, \mathrm{Ca}^{+2}$. 
$\mathrm{Na}^{+}\left(\mathrm{K}^{+}\right)$, though $\mathrm{Na}^{+}\left(\mathrm{K}^{+}\right)-\mathrm{Ca}^{+2}$ waters can also be found. The share of manganese ions in the cation composition is usually small and as the investigations of Pich (1980) show, it does not exceed $20 \%$ mval.

Table 1

Distribution of oxidation, sulphates, hardness and dry deposit values in the alluvial groundwater (after Blaszczyk and Górski 1976)

\begin{tabular}{|c|c|c|c|c|c|c|c|}
\hline \multicolumn{2}{|c|}{$\begin{array}{c}\text { Oxidation (mg/1) } \\
\mathrm{n}=89\end{array}$} & \multicolumn{2}{c|}{$\begin{array}{c}\text { Sulphates (mg/1) } \\
\mathrm{n}=70\end{array}$} & \multicolumn{2}{c|}{$\begin{array}{c}\text { Hardness }\left({ }^{\circ} \mathrm{n}\right) \\
\mathrm{n}=102\end{array}$} & \multicolumn{2}{c|}{$\begin{array}{c}\text { Dry deposit (mg/1) } \\
\mathrm{n}=91\end{array}$} \\
\hline range & $\%$ & range & $\%$ & range & $\%$ & range & $\%$ \\
\hline $0,0,3$ & 34 & $0,0-20$ & 41 & $0,0-4$ & $0,0-4$ & $0,0,0-200$ & 13 \\
$3-5$ & 34 & $20-50$ & 20 & $4-8$ & 11 & $200-400$ & 75 \\
$5-8$ & 28 & $50-100$ & 36 & $8-18$ & 84 & $400-500$ & 11 \\
8 & 4 & 100 & 3 & $18-30$ & 5 & $>500$ & 1 \\
\hline
\end{tabular}

n - number of samples

Table 2

Distribution of iron and manganium content in the alluvial groundwater (after Blaszczyk and Górski)

\begin{tabular}{|l|r|r|r|r|r|r|r|r|}
\hline \multirow{3}{*}{ Paleovalley } & \multicolumn{5}{|c|}{ Fe content (mg/1) } & \multicolumn{3}{c|}{ Mn content (mg/1) } \\
\cline { 2 - 9 } & $0.0-0.3$ & $0.3-2.0$ & $2.0-5.0$ & 5.0 & $0.0-0.1$ & $0.1-2.0$ & $2.0-5.0$ & 5.0 \\
\cline { 2 - 8 } & \multicolumn{4}{|c|}{ \% number of samples } & \multicolumn{3}{c|}{ \% number of samples } \\
\hline Barycz - Głogów & 0 & 33 & 50 & 17 & 3 & 94 & 3 & 0 \\
Warsaw - Berlin & 9 & 72 & 19 & 0 & 18 & 82 & 0 & 0 \\
Toruń - & 10 & 5 & 53 & 32 & 20 & 60 & 13 & 7 \\
Eberswalde & & & & & & & & \\
\hline
\end{tabular}

Nitrogen compounds, that is nitrites, nitrates and ammonia, are quite common in the valley waters.

\section{WATER CIRCULATION AND SOLID MATTER CIRCULATION}

The solid matter circulation in the alluvial valley is determined by the horizontal water exchange in which groundwater plays the main role. Four zones may be distinguished (Fig. 4) in the system of groundwater of the alluvial valley.

The first zone is the area in which groundwater occurs at such a depth that its table is beyond the reach of evaporation from the ground and these waters have no contact with soil waters; the groundwater table and its zone of capilary fringe is separated from the root zone of plants by a clear-cut zone of soaking water (Fig. 5a). Here the vertical transport of solid matter towards groundwater is prevalent; it may take place thanks to infiltration 


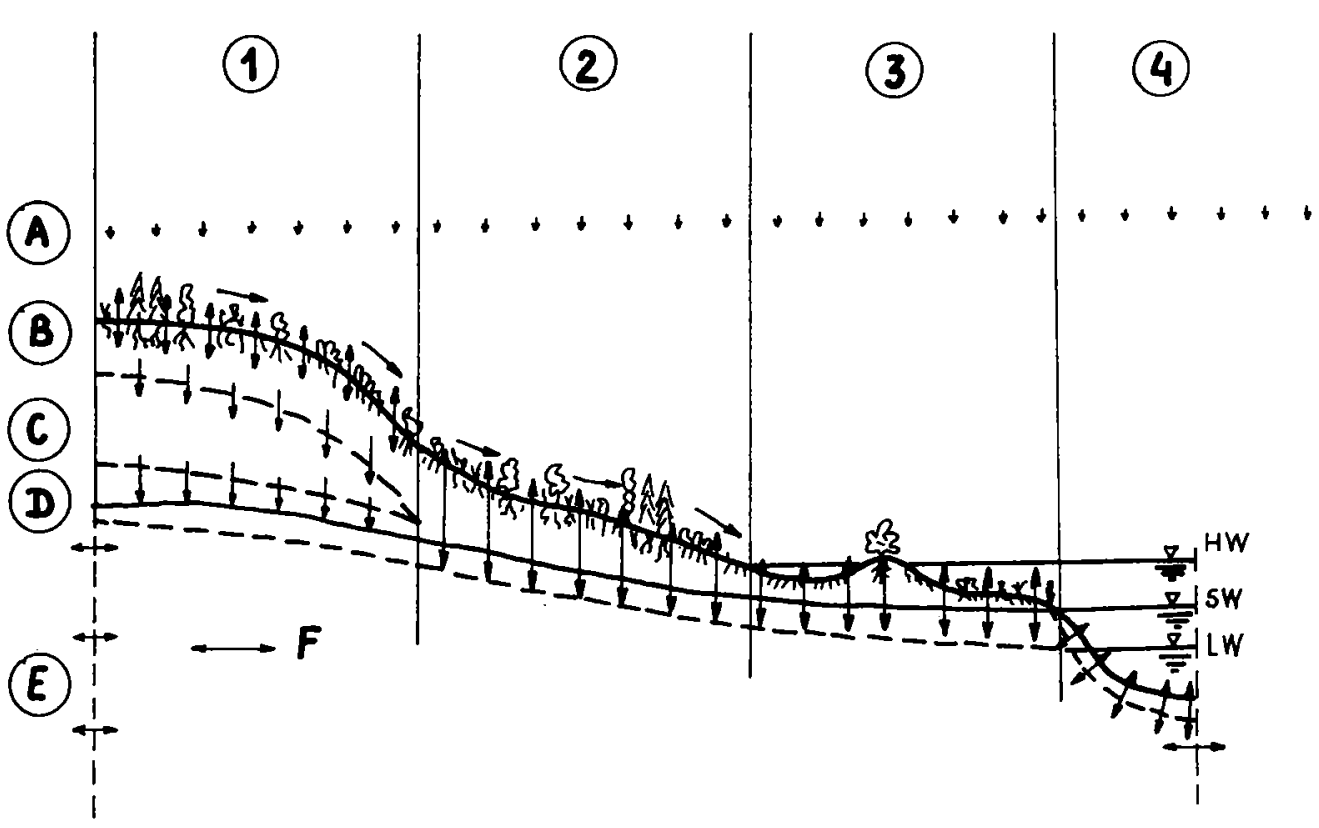

Fig. 4. Scheme of drainage and alimentation of groundwater in alluvial valley (after Herrmann et al. 1991); 1 - "Deep" aquifers with low water table, 2 - Shallow aquifers (groundwater and soil/root zone interactions), 3 - Flood plains (groundwater and surface water interactions, 4-River; A-Precipitation, B - Soil/root zone, C - Unsaturated zone, D - Fluctuating groundwater table, E - Adjacent aquifer compartments, F - Exchange of water, matter (nutrients, pollutants,...) and energy (pressure head, head,...)

of precipitation water. Solid matter going down to the ground is partly used by plants and partly - according to the lithology of the parent material assimilated chemically; but a considerable part of this matter in the shape of various salts, freely migrates (if there are no isolating layers in the subsurface layer) deeper to groundwater. This zone corresponds to autonomous surfaces characterized by the inflow of the prevalent substance from the atmosphere and by its constant transit (Perelman 1971).

The second zone is the area in which groundwater table is so shallow that is has a direct contact with the root zone of plants and thereby with soil waters (Figs. 4, 5b). Precipitation water relatively rapidly infiltrates into groundwater, enriching it with chemical compounds "washed out" from the soil. In the period of absence of precipitation, the movement of water and solid matter goes upward due to capilary fringe and soil evaporation. However, the prevalent process in this zone is the lateral inflow of substance and its periodic weak leaching.

The third zone comprises flood plain, that is the area in which groundwater and surface water remain in the direct hydraulic relationship. In this zone the level of groundwater table is shaped by infiltration of fluvial water and the lateral inflow of groundwater. Under these circumstances, the 


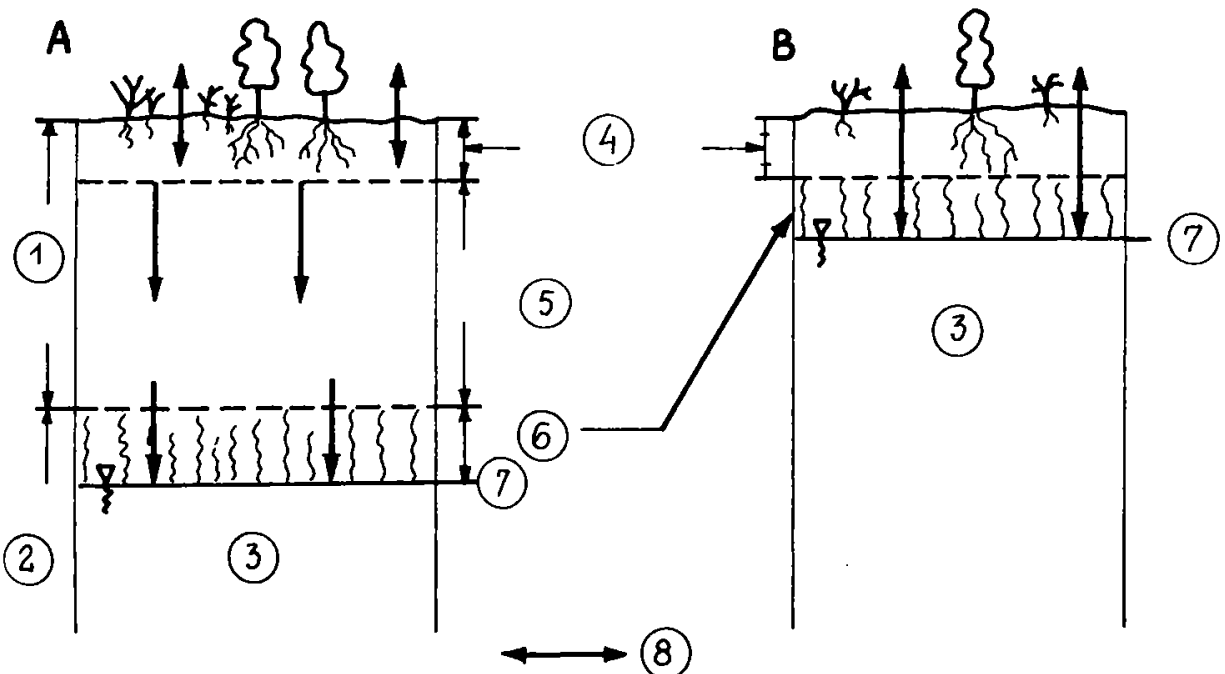

Fig. 5. Scheme of vertical exchange of water and solid matter within zones: $1(a)$ and 2(b), according to Fig. $4 ; 1$ - unsaturated zone, 2 - saturated zone, 3 - groundwater, 4 - soil/root zone, 5 - intermediate vadose zone, 6 - capillary fringe, 7 - groundwater table, 8 - exchange of water, energy and matter (nutrients, pollutants,...)

dominant process in solid matter circulation is the lateral inflow of substance and its very poor transit, which permits a considerable accumulation of chemical compounds and elements, mainly those marked by great migration ability. The zone plays a particular role in water and solid matter cicrulation in the alluvial valley. Flood plains situated in the lowest part of the valley bottom remain in the zone of direct influence of the river, even though only occasional. The surface of the flood plain is the place of accumulation of fluvial deposits or erosion. Under natural conditions, there occurs a constant exchange of deposits between the river channel and the flood plain; on the one hand, erosion of banks and surface of the flood plain is taking place, on the other hand, during floods large masses of deposits are left (the amount of deposits taking part in this process is usually larger than the volume of deposits transported along the river channel). Construction of ditches interrupts the process of flooding of the plain by flood water, thereby changing the manner of matter circulation within the plain.

The flood plain is constantly fed with groundwater coming from the higher levels (above-lying terraces and valley slopes), and periodically with precipitation water and river water. Its relationship with the higher levels is usually very strong due to similarity of the material forming the plain and terraces. By draining the entire valley the river causes the flow of ground and surface water from the valley slope up to its main bed. The same is the way of feeding of the flood plain with matter. For the solid matter transported by water the flood plain may be a transit or buffer area. In places where the river alluvia consist of sands and gravel the transport of 
solid matter does take place, because they are not a barrier to salts migrating deep down. However, alluvia with varying granulation, with organic substance and loamy formations, limit water and solid matter migration; on the one hand, heavier dusty formations reduce the rate of infiltration, but on the other hand they may assimilate chemically or exchange some ions.

The flood plain is also an area predestined to gather substance; there are many depressions of weak drainage here. Although it constitutes an area of a relatively rapid water exchange, it is very susceptible to disturbance in water circulation and changes in conditions of redox (e.g. as a result of exploitation of alluvial waters or drainage land improvements).

The fourth zone is the river channel; the stage of its filling decides whether the groundwater will feed the river waters with solid matter or whether the river waters (usually more polluted than groundwater) will supply water-bearing levels, thereby increasing mineralization of the alluvial waters.

The quantitative analysis of water and solid matter circulation in the alluvial valley requires detailed hydrological, geo- and hydrochemical investigations. They should be conducted on various scales. On the one hand, water and solid matter circulation should be assessed in homogeneous - in terms of water circulation - physico-geographical units, e.g. hydrotopes. On the other hand, its should be evaluated in the entire morphological unit as the alluvial valley is; it is not only the system of hydrotopes in the valley that determines the migration of matter or its accumulation but also interactions between surface and groundwater.

The authors intended to outline the problem undertaken by the Department of Hydrology of the Faculty of Geography and Regional Studies, University of Warsaw, in collaboration with the Department of Hydrology of the Johann Wolfgang University in Frankfurt-on-Main (Fachbereich Geowissenschaften), under the 4th phase of the UNESCO International Hydrological Programme) ${ }^{1}$.

\section{REFERENCES}

Alekin O.A., 1956, Podstawy hydrochemii (Foundations of Hydrochemistry), Warszawa, PWN.

Bajkiewicz-Grabowska E., 1988, "Kształtowanie się chemizmu wód gruntowych strefy podmiejskiej (na przykładzie gminy Lomianki)" (Formation of chemical properties of groundwater of the suburban zone. A case study of Lomianki village), Przgelgd Geograficzny, Vol. 60, No.1-2.

${ }^{1}$ International Hydrological Programme. Hydrology and water resources for sustainable development in a changing environment - Detailed Plan for the fourth phase of the IHP (1990-1995) as approved by the IHP Council at its Ninth session (Paris, 19-24 March, 1990); Project M-3-4: Flood plain pollution control management of the river Vistula (Poland) and Main (Germany) 
Błaszczyk T., Górski J., 1978, Zmiany jakości wód podziemnych w warunkach intensywnej eksploatacji (Changes in quality of groundwater under the conditions of intensive exploitation), Warszawa, IKŚ.

Falk ow ski E., 1971, "Historia i prognoza układu koryta wybranych odcinków nizinnych Polski" (History and forecast for the layout of the river channels of selected sections of lowland rivers in Poland), Biuletyn Geologiczny, Vol. 12

Golterm a n H.L., 1967, Influence of the soil on the chemistry of water in relation to productivity, FAO fish, Vol. 3, No.14.

Górski J., 1981, Ksztaltowanie się jakości wód podziemnych utworów czwartorzędowych $w$ warunkach naturalnych oraz wymuszonych eksploatacja (The shaping of the quality of groundwater of Quaternary formations under natural conditions and enforced by exploitation), Warszawa, IKS.

Herrmann R., Hubert P., Kobus H., 1991, "Groundwater", Journal of Hydrological Research, Vol. 29, Hydraulics and the Environment, Extra issue.

Laherno P., 1971, "On the hydrogeology of the coastal region of south-eastern Finland", Bulletin 252, Otaniemi.

Macioszczyk A., 1988, "Chemizm wód podziemnych oraz główne czynniki kształtujace go" (Chemical properties of groundwater and the main factors affecting it), Zeszyty Probl. Post. Nauk Roln. No 347.

Perel ma n A., Geochemia krajobrazu (Geochemistry of Landscape), Warszawa, PWN

Pich J., 1980, "Zmiany chemizmu wód gruntowych w otoczeniu sztucznych zbiorników wodnych w Dębem i Włocławku" (Changes in chemical properties of groundwater in the vicinity of man-made lakes at Dębe and Włocławek), Hydrogeological Works - extra series, No. 13, Warszawa, Wyd. Geol.

Plochniewski Z., Pich J., 1966, "Zelazo i mangan w wodach podziemnych różnych środowisk hydrogeochemicznych" (Iron and manganium in groundwater of various hydrogeochemical environments), Kwartalnik Geologiczny, Vol. 10, No.3.

Poźníak R., 1988, "Zasilanie dolin rzecznych wodami podziemnymi" (Recharge of the river valleys with groundwater), Zeszyty Probl. Post. Nauk Roln. No.347

Sk o m p ski S., 1969, "Stratygrafia osadów czwartorzędowych wschodniej części Kotliny Płockiej" (Stratigraphy of Quaternary deposits of the eastern part of the Płock Valley), Biuletyn PIG, 220.

Starkel L., 1991, "Historia dolin rzecznych w holocenie" (History of the river valleys in Holocene), in: Przemiany środowiska geograficznego, Wszechnica PAN, Ossolineum Wrocław. 